http://dx.doi.org/10.11646/phytotaxa.152.1.3

\title{
Notes on Early Land Plants Today. 44. Comments on sexuality in Solenostoma (Solenostomataceae, Marchantiophyta) and on some newly described taxa
}

\author{
JIŘÍ VÁŇA ${ }^{1}$, LARS SÖDERSTRÖM ${ }^{2}$, ANDERS HAGBORG ${ }^{3} \&$ MATT VON KONRAT $^{3}$ \\ ${ }^{1}$ Department of Botany, Charles University, Benátská 2, CZ-12801 Praha 2, Czech Republic; email: vana@natur.cuni.cz \\ ${ }^{2}$ Department of Biology, Norwegian University of Science and Technology, N-7491 Trondheim, Norway; lars.soderstrom@bio.ntnu.no \\ ${ }^{3}$ Science and Education, The Field Museum, 1400 South Lake Shore Drive, Chicago, IL 60605-2496, USA; hagborg@pobox.com, \\ mvonkonrat@fieldmuseum.org
}

\begin{abstract}
The sexuality of Solenostoma species is discussed and it is concluded that Solenostoma sanguinolentum is heteroicous. This and other morphological differences from Solenostoma marcescens are discussed and they are considered to belong to the same species. Heteroicity probably also occurs in Solenostoma micranthum and possibly in other Solenostoma species. Solenostoma rossicum and Solenostoma pyriflorum subsp. purpureum are new synonyms to Solenostoma sphaerocarpum. Solenostoma ochotense is a new synonym to Solenostoma hokkaidense. Solenostoma costaricanum is a new synonym to Solenostoma amoenum. Plectocolea subbalfourii is a new synonym to Solenostoma balfourii. Solenostoma rubrum var. underwoodii is a new synonym to Solenostoma rubrum. Plectocolea yunnanensis is a new synonym to Solenostoma sikkimense. Solenostoma inundatum var. grandirete is a new synonym to Solenostoma orbiculatum. Solenostoma kurilense and Solenostoma ovalifolia are new combinations and Solenostoma philippinense a new species.
\end{abstract}

Bakalin \& Vilnet (2012) described two new species and made one new combination in Solenostoma and two new combinations in Plectocolea. Bakalin (2013) described four more taxa in Solenostoma and two in Plectocolea based on specimens in NY. Recent molecular studies (e.g. Feldberg et al. 2009) have shown that the two genera, as traditionally defined, can not be separated which is also shown by the phylogenetic tree in Vilnet \& Bakalin (2012). Some of their Plectocolea species are therefore transferred to Solenostoma.

In their papers describing new taxa within Solenostoma and Plectocolea, Bakalin \& Vilnet (2012) and Bakalin (2013) made two oversights. Firstly, they compared several of their new taxa with species that are not closely related. Secondly, they overlooked to mention taxa that, based on previously published descriptions, morphologically would be the closest relatives. The differences from their apparently closest relatives are most often so small that they fall within the variation of the species. The present paper addresses these issues.

The format of this note follows that which is outlined in Söderström et al. (2012) except that the Melbourne code of nomenclature (ICN; McNeill et al. 2012) is followed instead of the Vienna code (ICBN; McNeill et al. 2006). All corresponding specimens in NY have been seen by the first author.

\section{The distinction between Solenostoma sanguinolentum and Solenostoma marcescens, and some notes on sexuality in Solenostoma}

Bakalin (2013: 139) re-established Jungermannia marcescens Mitten (1861:91) as a good species, Solenostoma marcescens (Mitt.) Bakalin (2013: 139), which Váňa (1973: 68) placed in synonymy of Solenostoma sanguinolentum (Griffith 1849: 302) Stephani (1901: 489). The experience with relatively copious material by the senior author allows the following comments on the proposed differences between Solenostoma sanguinolentum and Solenostoma marcescens. 
Sexuality of plants:-According to the literature information, Jungermannia marcescens is described as "dioica" (Stephani 1901: 503) or "dioicous?" (Amakawa 1967: 264). However, Amakawa states "the upper leaves are often ventricose as if they contained antheridia", but also "male inflorescence unknown". Solenostoma sanguinolentum is reported as "dioica" (Stephani 1901: 489) or "dioicous" (Amakawa 1967: 256). Bakalin (2013: 141) also wrote "Dioicous (? only female organs seen)". No other information about the sexuality of Solenostoma sanguinolentum or Solenostoma marcescens is known. Váňa (1973: 68) did not give any information about the sexuality of Solenostoma sanguinolentum, only the note that "the type material of Jungermannia marcescens Mitt. is identical in all characteristics with the material of Jungermannia sanguinolenta Griff...”. Váňa \& Long (2009: 507) also did not give any information about the sexuality of Solenostoma sanguinolentum, only saying "Androecia (previously unknown in this species) intercalary, bracts 5-7 pairs, relatively remote, slightly saccate at base." It is of course possible to assume that it can suggest that Solenostoma sanguinolentum (syn. Solenostoma marcescens) should be dioicous, but that was never explicitly said. Based on the above facts, the senior author was very careful and avoided publishing explicit information about the sexuality of Solenostoma sanguinolentum or Solenostoma marcescens.

In the years before 1972 (cf. Váňa 1973: 68) and also after 1972 the senior author examined almost all available material of Solenostoma sanguinolentum present in the herbaria BM, E, FH, G, JE, M, NICH, NY, TNS, and W, as well as the material of many recent collections (except some collections made by Chinese bryologists). Lectotypes and many iso(lecto)types of both Solenostoma sanguinolentum (BM - lectotype , FH, G-672, NY - isolectotypes) and Solenostoma marcescens (BM - lectotype, FH, G-14835, NY, Wisolectotypes) were also studied. The material coll. J. Poelt (det. Grolle, M, JE), as well as the collections of Japanese botanists (coll. Z. Iwatsuki, K. Yoda, det. Amakawa, NICH, TNS), the collections of G. and S. Miehe (det. Váňa, MB) and especially the collections of D. Long (det. Váňa, E) contains mostly very good, optimally developed material. Concerning the sexuality, the existence of pure gynoecial shoots with perianths (sometimes with 3-5 \pm saccate leaves just below the perianth or sometimes saccate leaves separated by 2-3 not saccate leaves from the perianth), pure androecial shoots (with terminal androecia and also intercalary androecia, terminating by $3-5$ pairs of sterile leaves up to the top of the shoot and no trace of archegonia) and one (- three?) paroicous shoot was confirmed.

Gynoecial shoots without saccate leaves below gynoecium were very common, they are present in nearly all specimens examined, as well as in the type specimens of Solenostoma sanguinolentum and Solenostoma marcescens. Gynoecial shoots with saccate leaves below gynoecium were not common, but they were found in the type material of Solenostoma marcescens, and in some other specimens (never in the type specimens of Solenostoma sanguinolentum). In contrast, pure androecial shoots were very rare. They were never found in the type specimens of Solenostoma sanguinolentum. Neither could Bakalin find the androecia in the isolectotype specimen in NY 967468. Two pure androecial shoots were found in the lectotype specimen of Solenostoma marcescens in BM (Bakalin did not mention pure androecial shoots in the specimen NY 961508), and sometimes found in the specimen coll. Yoda (det. Amakawa as Jungermannia sanguinolenta, TNS 11879), and coll. Long 21570 (det. Váňa as Jungermannia sanguinolenta, E). The issue is complicated by the fact that the leaves are relatively large and only slightly saccate (if at all) at their bases, not characteristically saccate as in many other species of Solenostoma. In the saccate leaves immediately below gynoecia antheridia were never found, only some sterile filaments and primordials of lateral branches were often present. Examination of the saccate leaves somewhat distant from gynoecium resulted in the finding (twice) of some traces which may be interpreted as the rest of antheridial stalk or something like a filament. Well developed antheridia with antheridial stalks were found only once in the course of re-examination of the isotype material of Solenostoma marcescens in BM. One leaf with two relatively well developed antheridia (open) was present. The antheridial stalks were 1-cell wide at the base, and, in part, 2-cells wide above.

Bakalin (at least according the information presented in the article) examined only the isotype specimens of Solenostoma marcescens and of Solenostoma sanguinolenta in NY and there is no information about the study of any additional specimens. He (Bakalin 2013: 139) found that "the type material of $J$. marcescens is paroicous, not dioicous as in $S$. sanguinolentum. Antheridia below the perianth are often lacking in this 
species, however, and are present in approximately every third shoot. This situation is rather common in the paroicous species of Solenostoma where antheridia are easily washed away when herbarium material is wetted. The paroicous state also suggested by the constant fertilization of the archegonia in the absence of antheridial shoots." This statement of Bakalin is correct, but he is not the first one showing the described problem.

It should be mentioned that Bakalin, who was the first to discover paroicous inflorescence in the isotype specimen of Solenostoma marcescens, like all previous authors considered Solenostoma sanguinolentum as dioicous (on the basis of examination of the isotype in NY) and on this basis as a separate taxon from Solenostoma marcescens. Unfortunately, it is not possible (at least in the present time by present methods) to confirm the statement by molecular methods because both types were collected in $19^{\text {th }}$ century.

Taking the above observations of Váňa and of Bakalin into consideration (both considered correct), we have only one species (where the name Solenostoma sanguinolentum has priority), highly proterandrous with heteroicous (not exactly paroicous nor exactly dioicous) inflorescence. The proposed new combination Solenostoma marcescens (Mitt.) Bakalin is superfluous and falls in the synonymy of Solenostoma sanguinolentum. Jungermannia marcescens Mitt. cannot be treated as a "good" species (as already stated by Váňa 1973: 68). Heteroicity is not unknown in the genus Solenostoma and similar genera, but it is not common. It has been reported a few times in Solenostoma paroicum (Schiffner 1910: 320) Schuster (1953: 402) (Váňa 1975: 83, Paton 1999: 285), Solenostoma subellipticum (Heeg 1893: 69) Schuster (1969: 1021) (Damsholt 2002: 232), Jungermannia pumila Withering (1796: 866) (cf., e.g., Damsholt 2002: 203, Váňa et Engel 2013: 76), Jungermannia polaris Lindberg (1867: 560) (Damsholt 2002: 206), and possibly also in Solenostoma obovatum (Nees 1833:332) Massalongo (1903: 17) (Paton 1999: 285). Also the presence of sterile leaves between perianth and androecium was mentioned e.g. for Jungermannia pumila, Solenostoma paroicum and Solenostoma subellipticum (Damsholt 2002: 227, 230).

It is also worth mentioning that Bakalin described Nardia geoscyphus (De Notaris 1859: 486) Lindberg (1874) var. dioica Bakalin et al. (2010: 87) on the basis of different sexuality only. (N. geoscyphus var. geoscyphus is paroicous). In the footnote on the same page Bakalin correctly presented the published information of Váňa (1976: 379) which in the type plants of Nardia geoscyphoides Amakawa (1957: 167) (described as dioicous) found two subinvolucral bracts on the female inflorescence with antheridial stalks and fragments of an antheridium wall; this species was reduced into synonymy of Nardia geoscyphus. Maybe Nardia geoscyphus var. dioica represents the same problem as was found in the cases of Nardia geoscyphoides and Solenostoma sanguinolentum / marcescens, simply high proterandry.

A probably identical case concerns Lophoziopsis excisa (Dickson 1793: 11) Konstantinova \& Vilnet (2010: 66) and Lophoziopsis propagulifera (Gottsche 1890: 451) Konstantinova \& Vilnet (2010: 67), discussed in detail in Váňa et Engel (2013: 75-76) where Lophoziopsis excisa is reported as paroicous and Lophoziopsis propagulifera as dioicous (Stephani 1902: 139), paroicous (Schuster 1969a: 521) or dioicous, rarely paroicous or autoicous (Bakalin 2005: 100). This problem was intensively studied by molecular methods by Vilnet et al. (2007, 2008); and the authors could not resolve Lophoziopsis propagulifera as a distinct species. In that study Lophoziopsis propagulifera (based on a specimen from the Kamchatka region) forms a separate clade with Lophoziopsis excisa (based on collections from the Murmansk area and Spitzbergen). They stated (Vilnet et al. 2008: 412) that "in view of the quite similar level of sequence divergences within Lophozia excisa, and between Lophozia propagulifera and Lophozia excisa, it is not possible to resolve the taxonomic status of Lophozia propagulifera. If we recognize the latter taxon at the species level, then the Spitzbergen specimens of Lophozia excisa should be treated as separate species, too." The cladograms in the molecular studies of Vilnet et al. $(2007,2008)$ reveal that Lophoziopsis propagulifera should be separated at the specific level only if we accept additional "microspecies" within the Lophoziopsis excisa complex and disregard influence of ecological factors on the sexuality of the plants. Maybe similar problems are more common in autoicous species where this phenomenon is more complicated as the autoicity sometimes is difficult to detect because of disintegration of basal parts of the shoots. The many times discussed and not yet fully clarified problem of Lophocolea bidentata / coadunata may be mentioned in this context (cf. also discussion in Váňa et Engel 2013: 41-43). 
Perianth:-Bakalin (2013: 139) stated "The perianth in $J$. marcescens is bistratose in the lower 2/3 of its length, and in S. sanguinolentum only in the lower third" and "The perianth of S. sanguinolentum is much larger than in $J$. marcescens (up to $6 \mathrm{~mm}$ long, vs. to $1.5 \mathrm{~mm}$ long)". In all of about 40 specimens examined by the senior author the perianths were bistratose from $1 / 4$ to $3 / 4$. Young perianths were bistratose only in the lower half whereas mature perianths were bistratose mostly to $2 / 3-3 / 4$. This character is naturally correlated with the length of the perianth and also with the length of the emergence of perianth from the female bracts. It should be mentioned that the perianths are fully mature in the type of Solenostoma sanguinolentum, which is the source of Bakalin's observation (and thus bistratose to 2/3-3/4 and 0.7-0.8 emergent), whereas the ones in the type of Solenostoma marcescens are not fully mature (and thus bistratose to $1 / 3-1 / 2$ and about 0.5 emergent). The maturity of the perianth is the reason no antheridia were found in the type plants of Solenostoma sanguinolentum by any author including Bakalin. Thus, bistratosity and the size of the perianth does not separate Solenostoma sanguinolentum from Solenostoma marcescens.

Colouration:-Bakalin (2013: 139) wrote "The typical coloration of $J$. marcescens plants is yellowish brownish to brown, as was noted by Mitten (1861), Amakawa (1966) and observed in the study of the first author. In contrast, the typical coloration of S. sanguinolenthum [sic!; in the article Bakalin used both forms: "sanguinolentum" and "sanguinolenthum"] is light to deep pink. As noted by Váňa (1972[=1973]) greencoloured plants of $S$. sanguinolenthum may occur, but the green coloration can be treated as merely the absence of secondary pigmentation. The presence of brown pigmentation versus pink in the well-exposed phases is quite another matter. Correlated with this feature is the rhizoid coloration; it is colorless to pinkish in S. sanguinolenthum versus brown to golden brown and red-brownish in J. marcescens."

This information (except "brown") is the same as presented in Amakawa (1966: 256, 264). It is more precise in Stephani (1901: 489 "superne sanguinea" and 508 "pallide flavo-virens"). Examining a wide spectrum of specimens, it will be found that the colour may be green, yellow-green, yellowish brown, pinkish to in some parts tinged with purplish. Also the type plants of Solenostoma marcescens have partly purplish perianths. The purplish colour is the reaction to the occurrence in sunny places (a similar situation is very well known e.g. in Mylia taylorii (Hooker 1813: pl. 57) Gray (1821: 693)). The colour of old specimens is mostly pale or yellowish, which probably is caused by the decolouration of green plants after many years. Recent collections (at least the ones examined) are mostly green and tinged with purple.

Rhizoid colouration should, according to Bakalin, be correlated with the colour of plants. The source of this information is probably Stephani $(1901: 489,508)$, who described rhizoids of Solenostoma sanguinolentum as "pallidis" and of Solenostoma marcescens as "purpureis". This statement cannot be fully confirmed; golden brown to red brownish rhizoids are also present in some plants of the type of Solenostoma sanguinolenta as well as in many other specimens, and this character is never correlated with the colour of leaves or perianths. Many times rhizoids of the same specimen may be light brown to intensive purple. Thus, "brown" rhizoids and "yellowish brownish to brown" pigmentation can not be used to separate Solenostoma marcescens and Solenostoma sanguinolentum.

Pachydermous leaf cell structure:-Bakalin (2013: 139) stated that " $J$. marcescens has rather pachydermous leaf cells, versus leptodermous in S. sanguinolenthum; this character correlates with the former's more rigid plant habit than the latter". This character was also given by Amakawa (1967: 264 "walls slightly thickened"). This character of cells, based on ecology (light), is not constant even in the type plants of Solenostoma marcescens as some plants have cells with thin walls. Bakalin's drawing (fig. 8: 5) also does not agree with this. Again, a wide spectrum of this character (slightly pachydermous to leptodermous cells) can be found in the examined material. Thus, we conclude that leaf cell structure (leptodermous or pachydermous) is based on the ecological conditions and cannot be used to separate the taxa mentioned.

Bakalin (1.c.: 139) also stated that Solenostoma marcescens resembles species of the Solenostoma pyriflorum Stephani (1917a: 83) group, whereas Solenostoma sanguinolentum is similar to those of the Solenostoma fusiforme (Stephani 1897: 99) Schuster (1969: 944) group. It is difficult for us to find similarity with Solenostoma pyriflorum or with Solenostoma fusiforme. Unpublished molecular data also confirms that Solenostoma sanguinolentum is very distantly related to Solenostoma pyriflorum and Solenostoma fusiforme. 
Conclusions:-Based on the characters discussed above, Bakalin (2013) concluded that Solenostoma marcescens "is a 'good' taxon which is rather distant from S. sanguinolenthum" and makes the necessary combination under Solenostoma. Our observations show no difference between Solenostoma sanguinolentum (if we accept the heteroicous inflorescence for the taxon) and Solenostoma marcescens on the morphological basis as the facts discussed above confirm the opinion presented in Váňa (1973: 68) and Ván̆a et Long (2009: 507) treating the taxa as conspecific. Until population studies based on molecular methods are at hand, there is no reason to keep the two taxa apart.

\section{Plectocolea micrantha}

Bakalin (2013: 137) states that Solenostoma micranthum (Mitten 1873: 405) Váňa et al. (2010: 137) probably is paroicous, not dioicous as thought until now. He found androecia just below the perianth which Mitten (1873: 405), who described this species, did not find (according to Bakalin probably because they are disappearing very quickly after fertilization), but Stephani (1901: 503), who only received one shoot, found intercalary androecia. In the description of the type Bakalin wrote "androecia just below perianth" which does not correspond with "intercalary androecia" described by Stephani (and confirmed by the senior author on the G specimen from herb. Stephani). Bakalin did not present figures of paroicous plants (fig. 7:2 showed only three antheridia, and archegonia are not in this figure as stated in the legend). If the statement of Bakalin is correct, Solenostoma micranthum is probably not paroicous, but heteroicous (cf. e.g. Jungermannia pumila and probably some other taxa incl. Solenostoma pseudopyriflorum Bakalin \& Vilnet (2010: 159)).

\section{Solenostoma pseudopyriflorum / Solenostoma pyriflorum}

The above discussion brings up the question of the taxonomy of the Solenostoma pseudopyriflorum / pyriflorum complex including Solenostoma rishiriense Amakawa (1956: 48), which Bakalin \& Vilnet (2010: 159 ) accepted as a separate species. Solenostoma pseudopyriflorum was separated by Bakalin \& Vilnet (1.c.: 160) from Solenostoma pyriflorum on the basis of the paroicous inflorescence. In the same study they (1.c.: 160) stated "one of its striking features is an easy disintegration of antheridia and only loosely or almost not inflated base of male bracts". Some of the specimens were formerly recorded as Solenostoma rishiriense (Gambaryan 1992, Bakalin 2009a: 230) and Solenostoma pyriflorum (Váňa \& Ignatov 2005, Bakalin 2009b:108). It should be mentioned that the identification of two specimens by the senior author (attributed to Solenostoma pseudopyriflorum by Bakalin \& Vilnet 2010: 160) was based only on the fact that one specimen has only terminal androecia and the second one is fully sterile (at least the parts of specimens available for examination).

The separation of Solenostoma pseudopyriflorum is partly supported by molecular data (trnL-F cpDNA). In Bakalin \& Vilnet (2010: 153) in both maximum parsimony and maximum likelihood phylogenetic trees Solenostoma pseudopyriflorum ( 5 specimens from Eastern Siberia) form a separate clade sister to a clade based on two specimens of Solenostoma pyriflorum from South Korea (from the same or nearly the same locality). Solenostoma pseudopyriflorum demonstrates "a stable and almost invariable sequence pattern over extensive territory of about $300 \mathrm{~km}$, from Baikal to Kuril Islands" (1. c.: 155) and the "data support the segregation of Solenostoma pseudopyriflorum as a separate species distinct from S. pyriflorum." It should be only mentioned that Solenostoma pseudopyriflorum replaces Solenostoma pyriflorum north of $40^{\circ} \mathrm{N}$ latitude. In the study Bakalin \& Vilnet (2012: 570) used the combined $\operatorname{trn} L-F+\operatorname{trn} G$ intron nucleotide sequence where Solenostoma pseudopyriflorum forms a separate basal clade in the major clade formed by Solenostoma pyriflorum, Solenostoma major (Hattori 1950: 8) Bakalin \& Vilnet (2012: 574) (= Solenostoma pyriflorum var. major (S.Hatt.) Bakalin (2009a: 230)) and "Solenostoma sp.". 
Bakalin et Vilnet (2012: 571) also described a new species Solenostoma rossicum stated to be similar to Solenostoma sphaerocarpum, but differing in common presence of reddish pigmentation and heteroicous inflorescence. In the phylogenetic tree (using a Bayesian approach) five specimens of Solenostoma rossicum form a separate clade to Solenostoma sphaerocarpum, formed by two clades based on nine specimens analysed from Russia and Svalbard. Based on the molecular data obtained, the authors concluded that in spite of the low molecular divergence ("without significant support") between Solenostoma rossicum and the related species (e.g. Solenostoma sphaerocarpum and Solenostoma confertissimum (Nees 1833: 277) Schljakov (1980: 239), probably also with Solenostoma caucasicum (Váňa 1970: 96) Konstantinova et al. (1992: 123) compared to the other taxa discussed by them), they preferred to treat Solenostoma rossicum as a separate species due to its "heteroicous inflorescence, a noticeable whitish to pale brownish colored stem especially in the lower part, and a peculiar absence of sepia or sepia-brown pigmentation".

The two morphological features used to distinguish the new species are colouration and heteroicous inflorescences. Reddish pigmentation is present only in the form of "purplish red colored leaf margin and the shoot tips" (1.c. p. 571) or "only in the perianth tips" (1.c. p. 573). In spite of contradictory information on different pages of the same study it is clear that the purple colour is present only in the most exposed parts of the plants. Reddish colour was not reported until now in Solenostoma sphaerocarpum except for the information in the description of Jungermannia pusilla (Jensen 1912: 92) Buch (1936: 71) in Amakawa (1960: 59 "tinged with purple"). Japanese specimens of Jungermannia pusilla were erroneously identified and belong to Solenostoma sphaerocarpum (Váňa 1974c: 396). The "pale brownish colored stem especially in the lower part, and the peculiar absence of sepia or sepia-brown pigmentation" in Solenostoma rossicum falls within the variability of the very polymorphous Solenostoma sphaerocarpum. Bakalin \& Vilnet also stated that although the main diagnostic feature of the new species is a heteroicous inflorescence they are describing both a "paroicous phase" and a "dioicous phase". The occurrence of "paroicous phase" and "heteroicous phase", as the they wrote (1.c.: 573) is not surprising. This situation is not unknown in the genus Solenostoma and similar genera, but it is not common (cf. above).

Solenostoma sphaerocarpum is distributed in Siberia across the whole Siberian Arctic, Solenostoma rossicum in Khabarovsk territory, Sakhalin I. and Kuril Islands. It should be added that one voucher specimen for the molecular analysis used in the mentioned paper was from Yakutia Rep. (outside of the mentioned area). Moreover, from the neighboring Japan only Solenostoma sphaerocarpum was reported.

Our opinion on Solenostoma rossicum is influenced by the above discussion about proterandry and heteroicity of Solenostoma sanguinolentum, Jungermannia pumila and other species. It is a question if the highly proterandric, common and widely distributed species (not only in North America, Eurasia, but also in South America, Africa etc.) may, under the specific circumstances occur as a heteroicous taxon. It is possible that in the very limited range (Khabarovsky territory, Sakhalin I. and Kuril Is.) some genetical segregation occurs. But this question may be only answered by population and molecular studies of Solenostoma sphaerocarpum using voucher specimens from different areas. The present results of the molecular study (not fully significant according to the authors) and the above mentioned information about morphology and phytogeography support the opinion that Solenostoma rossicum represents a "heteroicous phase" of Solenostoma sphaerocarpum only.

The above opinion was confirmed by the re-study of a paratype specimen (coll. K. Holmen 14.643, C!, PRC!) of Solenostoma pyriflorum subsp. purpureum (Schuster \& Damsholt 1974: 178) by the senior author. The mentioned taxon was transferred to Solenostoma sphaerocarpum as Jungermannia sphaerocarpa subsp. purpurea (R.M.Schust. \& Damsh.) (Damsholt 2011: 102). The difference from Solenostoma sphaerocarpum subsp. sphaerocarpum is the "heteroicous rarely paroicous" inflorescence, "shoot usually with purplish secondary pigmentation" and "small-leaved shoots frequently present" (the last character concerns var. innovata). Comparing the isotype specimen (var. purpureum) with the description of Solenostoma rossicum no difference was found. It should be mentioned that Solenostoma pyriflorum subsp. purpureum var. 
innovatum Schuster \& Damsholt (1974: 179) may belong to Solenostoma confertissimum because of larger median leaf cells and the presence of small-leaved shoots typical for this species.

Solenostoma sphaerocarpum (Hook.) Steph., Bull. Herb. Boissier ser. 2, 1:499 (Spec. Hep. 2:61), 1901 (Stephani 1901). Basionym: Jungermannia sphaerocarpa Hook., Brit. Jungerm.: tab. 74, 1815 (Hooker 1815). Lectotype (Váňa 1974c): IRELAND. Dublin, 1814, Taylor (FH!).

= Solenostoma rossicum Bakalin \& Vilnet, Bryologist 115: 571, 2012 (Bakalin \& Vilnet 2012) "rossica", syn. nov. Type:

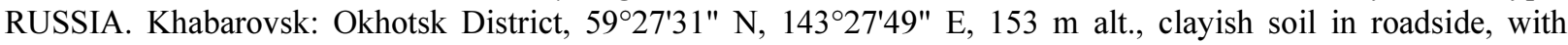
Nardia japonica Steph., 26 July 2008, V. Bakalin Kh-40-4-08 (holotype VBGI, isotype KPABG).

= Solenostoma pyriflorum subsp. purpureum R.M.Schust. \& Damsh., Hep. West Greenland: 178, $1974=$ Jungermannia pyriflora subsp. purpurea (R.M.Schust. \& Damsh.) Damsh., Lindbergia 33: 102, 2011, syn. nov. Type: GREENLAND. Kangersuneq, R. M. Schuster \& K. Damsholt 70-3145a (isotype C!); Svartenhuk Pen., Umiarfik Fjord, Amitsoq, 15 July 1956 K. Holmen 14.643 (paratype C!, small isoparatype PRC!)

\section{Solenostoma major}

Bakalin \& Vilnet (2012: 574) elevated Solenostoma pyriflorum var. major to specific rank. The molecular data for this and their value was already discussed under Solenostoma rossicum above. Morphologically, this taxon is separated from Solenostoma pyriflorum by the following characteristics: a) "deep purple rhizoid coloration versus colorless to brownish and light rose in S. pyriflorum". However, the rhizoids in the Japanese plants including the type are "colorless or purple" (cf. Amakawa 1960: 62). b) "wide, flattened, undulate and distant leaves versus concave, not undulate and contiguous leaves". Again, Japanese plants including the type have "somewhat concave" and not undulate leaves (cf. Amakawa 1960: 62). c) A tendency to occupy wet habitats. This character is based on only two specimens from South Korea collected on "banks of stream, where it is commonly growing submerged" (but Solenostoma pyriflorum also occurs on wet rocks). Thus, we regard the taxon as a modification that with the present knowledge at most deserves recognition at varietal rank.

\section{Solenostoma ochotense}

Bakalin \& Vilnet (2012: 575) described Solenostoma ochotense from plants collected in Kamchatka and the Kuril Islands. Samples in their molecular phylogeny come out as a monophyletic group sister to Solenostoma fusiforme and they compare it with this species, Solenostoma koreanum Stephani (1917a: 81) and Solenostoma hyalinum (Hooker 1814: tab. 63) Mitten (1870: 319). However, no samples of Solenostoma hokkaidense were included in their phylogeny and they do not mention that taxon at all although it is described from the region. Type plants of Solenostoma hokkaidense are poorly developed, where as Bakalin's plants are mostly optimally developed. Based on this fact, the leaf cells in Russian plants (especially the basal ones) are larger than in the type plants, but falls within the range of variation. This is probably an endemic taxon known only from Kamchatka Peninsula and Kuril Is. in Russia and Rishiri I. (Japan), the area of extant or extinct volcanic activity.

Solenostoma hokkaidense (Váňa) Váňa, Hentschel et J. Heinrichs, Cryptogamie Bryologie 31: 137, 2010 (Váňa et al. 2010). Basionym: Jungermannia hokkaidensis Váňa, J. Hattori Bot. Lab. 35: 314, 1972 (Váňa 1972).

= Jungermannia subelliptica var. nana Amakawa, J. Hattori Bot. Lab. 22: 21, 1960 (Amakawa 1960). Type: JAPAN. Hokkaido: Rishiri Is., 24 July 1954, D. Shimizu (holotype NICH-53484!).

= Solenostoma ochotense Bakalin et Vilnet, Bryologist 115: 575, 2012 (Bakalin \& Vilnet 2012) "ochotensis", syn. nov.

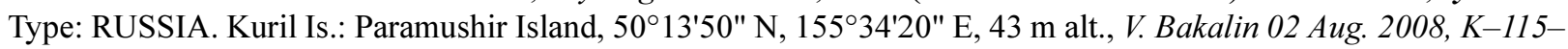
4-04 (holotype VBGI, isotype KPABG). 


\section{Plectocolea kurilensis}

Bakalin \& Vilnet (2012: 569) wrote "The relationship observed here between $P$. kurilensis and clade of $P$. rigidula and three poorly known Plectocolea species from South Korea is not well supported..." "Therefore, P. kurilensis appears to be a more heterogeneous species, with a complicated infraspecific structure that could be clarified by analyzing additional samples". Bakalin (1. c.: 579) considered this species "most superficially similar to both $P$. infusca s. str. and $P$. rosulans" and compared it with the two mentioned species. However, the phylogenetic tree based on combined $\operatorname{trn} L-F+\operatorname{trn} G$ does not show the close relationship of Plectocolea kurilensis to Solenostoma infuscum (Mitten 1891: 196) Hentschel et al. (2007: 152) and Solenostoma rosulans (Stephani 1897: 101) Ván̆a \& Long (2009: 507). Moreover, in the cladogram two specimens of Plectocolea kurilensis from Japan are included, which are not mentioned in the description of Plectocolea kurilensis. Because the authors gave no information about the localities of voucher specimens, nothing more is known about these samples. They are placed in the basal position and they may represent "morphologically ambiguous samples" (1.c.: 569). In our opinion, the plants of this species are much more similar (morphologically) to Plectocolea ovalifolia than to any of the above mentioned species, at least according to drawings (l.c.: fig. 5 and 6). This taxon seems to be problematical and heterogeneous, and future studies on molecular and morphological basis will probably help to clarify its value. In the meantime a transfer to Solenostoma is necessary.

Solenostoma kurilense (Bakalin) Váňa, comb. nov. Basionym: Plectocolea flagellata var. kurilensis Bakalin, Arctoa 18: 90, 2009 [2010] (Bakalin et al. 2010). Type: RUSSIA. Kuril Is.: Iturup Island, valley of

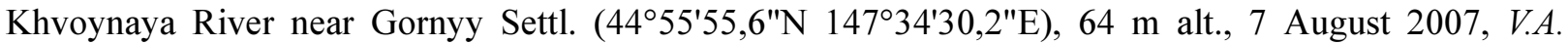
Bakalin, K-10-1-07 (VLA)

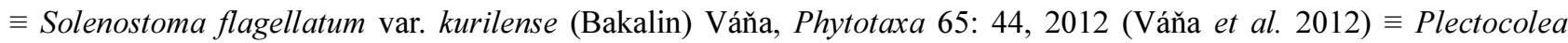
kurilensis (Bakalin) Bakalin et Vilnet, Bryologist 115:577, 2012 (Bakalin \& Vilnet 2012).

\section{Plectocolea ovalifolia}

The morphological differences between Plectocolea ovalifolia and Solenostoma infuscum (var. infuscum) are small (only uniformly oval leaves are significant). The size of plants and purple rhizoids are not important differences as the same size and purple rhizoids are known also in Solenostoma infuscum. However, according to molecular data (Bakalin \& Vilnet 2012: 569) it probably represents a good taxon of specific rank (belonging to different clades) and they elevate Plectocolea infusca var. ovalifolia to the species rank, Plectocolea ovalifolia. A transfer to Solenostoma is necessary.

Solenostoma ovalifolium (Amakawa) Váňa, comb. nov. Basionym: Plectocolea infusca var. ovalifolia Amakawa, J. Jap. Bot. 34: 115, 1959 (Amakawa 1959). Type: JAPAN. Hokkaido: Esan nr. Hakodate, Kuwahara 5758 (holotype NICH!).

三Solenostoma infuscum var. ovalifolium (Amakawa) Potemkin \& Sofronova, Pečënočniki i antocerotovye Rossii 1: 287, 2009 (Potemkin 2009). $\equiv$ Plectocolea ovalifolia (Amakawa) Bakalin et Vilnet, Bryologist 115: 579, 2012 (Bakalin \& Vilnet 2012).

\section{Solenostoma costaricanum}

Some years ago, at a visit to the NY herbarium, the senior author studied the specimen and identified it as Jungermannia amoena (now Solenostoma amoenum). The sentence in Bakalin (2013: 129) "The specimen was identified as Jungermannia (Solenostoma) amoena Lindenb. \& Gottsche..." concerns this determination. Bakalin disagrees with this determination and described and figured a new species, Solenostoma costaricanum, on the basis of this specimen. He compared it with Solenostoma crassulum (Nees \& Montagne 1836: 54) Stephani (1901: 497) and Solenostoma amoenum. The comparison with Solenostoma crassulum 
does not deserve any comments since that the observations are correct but the two taxa are not closely related. There are more differences between them that is not mentioned by Bakalin. Concerning the differences from Solenostoma amoenum Bakalin's descriptions are quoted below, followed by our comments: a) "androecia in 3-4 pairs (vs. 6-12)". The difference is based on the description by Váňa (1974a: 189). But the number of male bracts is not fully constant, in the time of the writing of the description the senior author saw only optimally developed specimens with 6-12 pairs and specimens studied later showed that the variability of this character is wider. b) "sometimes a shortly beaked perianth mouth (vs. rounded, not beaked)", but in the description the author wrote "commonly very weakly beaked or not beaked mouth". Also the character is very variable and of no taxonomic significance. c) "flaccid shoots (vs. rigid)". Again only ecological adaptation of no taxonomic value. d) "absence of a perigynium (vs. common presence)" compare again the description by Váňa (1974a: 183): "Perigynium vorhanden oder fehlt" [perigynium present or missing].

As an addition it should be mentioned that the drawing is not instructive and not fully corresponding with the description, e.g. "leaves... transversely elliptic to reniform", "leaf cells ... along margin ... thin-walled, with thin- to slightly thickened external wall...". All characters of this specimen fall within the variability of Solenostoma amoenum.

Solenostoma amoenum (Lindenb. et Gottsche) R.M.Schust. ex Váňa, Hentschel et Heinrichs, Cryptog. Bryol. 31:136, 2010 (Ván̆a et al. 2010). Basionym: Jungermannia amoena Lindenb. et Gottsche, Syn. Hepat. 5: 674, 1847 (Gottsche et al. 1847). Type: MEXICO. Oaxaca: Talea, 5000', 1842 Liebmann, Pl. mex. 10434 (Pl. mexic. Liebmann 250a) (lectotype: C!, isotypes S!, W-Lindenb. Hep. 1732!)

= Solenostoma costaricanum Bakalin, Polish J. Bot. 58: 128 (Bakalin 2013), syn. nov. Type: COSTA RICA. Alajuela: Calera de San Ramon, 29 January 1934, A. M. Brenes 19033 (holotype NY 636521!).

\section{Plectocolea subbalfourii}

In the examination of the duplicate specimen of the type of Bakalin's new species Plectocolea subbalfourii, received as a gift from T. Pócs by the senior author, only sterile plants were found, intermixed with plants of Marchantia and Riccardia. Recently the richer isotype specimen (Bakalin examined the smaller duplicate deposited in NY; moreover the first author have also a smaller duplicate) from the herbarium of Prof. T. Pócs (coll. Vojtkó/A,B,C; EGR) was received for re-examination. Between rhizoids of Marchantia one shoot with a perianth of "Plectocolea"-type was found. Based on this, the former identification by the senior author as Jungermannia borgenii Pearson (1892: 11) [=Solenostoma borgenii (Pearson) Stephani (1901: 493)] must be corrected. Bakalin (2013: 129) compared the specimen with Solenostoma balfourii, which was described on the basis of very sparse and poorly developed plants also from NY herbarium. He does not mention if he examined the type of Solenostoma balfourii, but he apparently compared the plants with the original description. According to Bakalin the differences from Solenostoma balfourii are as follows: a) "a higher perigynium ca. $0.6-0.7$ of perianth length (vs. $0.3-0.5$ of perianth length in Solenostoma balfourii)". One shoot with perianth found in EGR specimen has perigynium only ca. 0.4 of the perianth length (not $0.6-0.7$ of the perianth length). b) "obliquely to erect spreading rhizoids, mostly not fasciculate (vs. forming more or less clear fascicles)". The rhizoids in the original (EGR) and duplicate (PRC) specimens sometimes (in the perianth bearing plant) form a decurrent fascicle, in the sterile shoots the fascicle is "less clear". c) "not rhizogenous leaves (vs. rhizogenous)". In the original description by Váňa (1974b: 280) rhizoids are mentioned as "von basalen Blatt- und Perigyniumzellen entspringend" [originating from basal leaf and perigynium cells], which does not fully correspond to the term "rhizogenous leaves". In the specimens examined the rhizoids originate also from basal leaf cells and perigynium cells as in original specimen. d) "larger midleaf cells, up to $70 \times 57 \mu \mathrm{m}$ (vs. 28-35 $\mu \mathrm{m}$ )". In the original description (based on poorly developed plants) the marginal cells are 25-30 $\mu \mathrm{m}$, median ones $28-35 \mu \mathrm{m}$ and the basal ones 45-60 × 30-35 $\mu \mathrm{m}$. EGR and PRC specimens have the median cells a little bit larger (median cells 30-50 $\mu \mathrm{m}$, basal ones up to $65 \mu \mathrm{m})$. In fact, the cells of well developed plants of Solenostoma balfourii are a little bit larger than in the 
type specimen. The larger cell size for the species was confirmed by the study of one additional specimen of this species known from Réunion (coll. Gimalac 75.R.963; herb. Onraedt). In addition, Bakalin (2013: fig. 2: $8,9)$ does not show smooth cell surface although the description state "cuticle smooth".

Solenostoma balfourii (Váňa) Váňa, Hentschel et Heinrichs, Cryptog. Bryol. 31: 136, 2010 (Váňa et al. 2010). Basionym: Jungermannia balfourii Váňa, Folia Geobot. Phytotax. 9(3): 279, 1974 (Váňa 1974b). Type:-MAURITIUS, Balfour, det. Mitten as $J$. dusenii (holotype: NY-Mitten!)

= Plectocolea subbalfourii Bakalin, Polish Bot. J. 58: 129, 2013 (Bakalin 2013), syn. nov. Type: REUNION. E edge of Cirque de Mafate, on rocky N slope of Plateau de La Sale, along path, 26 August 1994, A. Vojtkó 9429 (holotype NY 1717834!, isotypes in EGR!, PRC!).

\section{Solenostoma rubrum var. underwoodii}

Bakalin (2013: 131) described the new variety from the NY copy of Hepaticae Americanae [not Exsiccatae Hepaticae Americanae] no. 169. The following comments are based on the description of Solenostoma rubrum in Váňa (1974c: 398-399) and on the examination of one of the three mentioned specimens distributed in the exsiccata Hepaticae Americanae no. 169 from the herbarium FI. Bakalin distinguished his new variety from the nominal variety in the following way: a) "purplish pale violet coloration (vs. commonly red coloration in var. rubrum)". Váňa (1974c: 398) states "In schwach bis stark purpurroten, seltener in grünen bis gelbgrünen ... Rasen..." [in somewhat to intensive purplish, rarely in green to yellow-green patches...]. Some specimens of Solenostoma rubrum are not completely red and the FI specimen of Hepaticae Americanae no. 169 has mostly pinkish to pale red colour, some shoots are red. (cf. also e.g. Frye \& Clark 1943: 330 "green to reddish green". b) "very small to virtually absent trigones inward of the leaf margin (vs. well developed)". In the FI specimen the trigones are small, but not absent. c) "mostly subequally thickened leaf rim cells (vs. strongly unequally thickened, commonly with large trigones)". Nearly all specimens of Solenostoma rubrum examined have sub-equally thickened marginal leaf cells. d) "a long exserted perianth (up to $4 / 5$ or even more vs. shortly to $1 / 2-3 / 5$ of its length exserted)". This character is depending on the maturity of perianth. We do not see any morphological differences from Solenostoma rubrum justifying a separation as a new taxon.

Solenostoma rubrum (Gottsche ex Underw.) R.M.Schust., Hepat. Anthocerotae N. Amer. 2: 975, 1969 (Schuster 1969). Basionym: Jungermannia rubra Gottsche ex Underw., Bot. Gaz. 13: 113, 1888 (Underwood 1888). Type: USA. California: Mendocino Co., "metamorphic sandstone quite near the Coalt Mendocine City" Bolander (lectotype: FH!, isotypes G!, M).

= Solenostoma rubrum var. underwoodii Bakalin, Polish Bot. J. 58: 131, 2013 (Bakalin 2013), syn. nov. Type: USA. Washington: King Co., Seattle, 12 Apr. 1891, C. V. Piper 21 (holotype NY 564814, isotype FI!).

\section{Plectocolea yunnanensis}

According to Bakalin (2013: 132) this new species from the Solenostoma truncatum (Nees 1830: 29) Váňa \& Long (2009 : 509) complex is closely related to Plectocolea boninensis (Horikawa 1934: 142) Hattori (1944: 37), Plectocolea granulata (Stephani 1897: 100) Bakalin (2013: 132) and Plectocolea shinii (Amakawa 1970: 156) Bakalin (2013: 132), all of which were synonymized by Ván̆a and Inoue $(1983: 132,134)$ with the very common and variable Solenostoma truncatum. Bakalin (1.c.: 133) with his narrow species concept of Solenostoma accepted the three above mentioned species as separate taxa and regarded the decision of Váña \& Inoue $(1983: 132,134)$ as "premature" and "additional studies including molecular analyses are needed to resolve this question." We agree with this reasoning, yet we maintain there is no new evidence at hand to warrant recognition of these taxa However, Bakalin's new species is fully identical with Solenostoma sikkimense, a species not at all mentioned in the text. 
Solenostoma sikkimense (Schiffn. ex Steph.) Váňa et D.G.Long, Nova Hedwigia 89: 508, 2009 (Váňa \& Long 2009). Basionym: Jungermannia sikkimensis Schiffn. ex Steph., Sp. Hepat. (Stephani) 5: 92, 1917 (Stephani 1917b). Type: INDIA. Sikkim, Kurseong, Ambutia, 610 m, 22 Nov 1899 Decoly \& Schaul (Herb. Levier 644) (holotype: G-548!, isotypes FI!, O!)

= Plectocolea yunnanensis Bakalin, Polish Bot. J. 58: 132, 2013 (Bakalin 2013), syn. nov. Type: CHINA. Yunnan: Cangyuan Co., Banhong-Xiang, Nangunhe Nature Reserve, 17 Nov 2009, W. Ma 09-0698 (holotype NY 1717750!).

\section{Solenostoma gracillimum subsp. camiguinense}

Bakalin (2013: 134) described a new subspecies of the mainly northern boreal and temperate Solenostoma gracillimum (Smith \& Sowerby 1811: tab. 2238) Schuster (1969: 972) and stated that the plants differ from typical Solenostoma gracillimum f. crenulatum (Mitten 1865: 51) Schuster (1969: 980) in "concave to slightly convex trigones in the midleaf (vs. virtually absent), commonly not beaked mouth (vs. uniformly beaked) and the perianth bistratose in lower third (vs. unistratose to base)". Slightly thick-walled cells, loosely striolate cell surface (cuticle) and absence of perigynium may also be added.

Contrary to Bakalin's view that these differences as well as the collecting site's extreme geographical isolation from the other localities of Solenostoma gracillima qualify for a subspecific rank, there is strong evidence that the plants should be separated on the species level. The new taxon is clearly different from all species of Solenostoma with leaves bordered by one row of thick-walled cells [i.e. Solenostoma fusiforme, Solenostoma gracillimum, Solenostoma handelii (Schiffner 1909: 135) Müller (1947: 38), Solenostoma limbatifolium (Amakawa 1968: 112) Váňa \& Long 2009: 504), Solenostoma rubrum, Solenostoma suborbiculatum (Amakawa 1968: 112) Váňa \& Long (2009: 508)], moreover, it is not closely related to Solenostoma gracillimum nor to Solenostoma fusiforme. It is probably most closely related to the Himalayan Solenostoma suborbiculatum, which differs from the new species by a suite of characters including: thinwalled, larger leaf cells (only marginal leaf cells thick-walled, only slightly larger than inner cells); leaves with a nearly smooth cell surface; leaves not widely orbicular-reniform;,perianth plicate only in terminal portion and with a distinct beak; and the presence of an erect perigynium, etc. A new name for the taxon is provided below.

Solenostoma philippinense Váňa, sp. nov.

Description:-The description in Bakalin (2013: 134 sub Solenostoma gracillimum subsp. camiguinense) validates the taxon.

Holotype:-PHILIPPINES. Is. of Camiguin, from around the fumaroles at the base of the New Volcano thrown up in 1871, Challenger Expedition s.n. s.d. (NY 1717840!).

三Solenostoma gracillimum subsp. camiguinense Bakalin, Polish Bot. J. 58: 134, 2013 (Bakalin 2013).

Note:- The senior author has chosen a new name for the species following ICN recommendation 23A.3(j) since the species likely occurs beyond Camiguin Island.

\section{Solenostoma inundatum var. grandirete}

Bakalin (2013: 137) described a new variety and compared it with Solenostoma inundatum (Hooker f. \& Taylor 1844: 559) Stephani (1901: 490) and Solenostoma rufiflorum (Colenso 1886: 237) Engel (2007: 312). Moreover, he wrote "The differentiating features may be regarded as induced by habitat conditions." However, the specimen is - according to the description and figures (Bakalin 2013: 135-137, fig. 6) fully identical with Solenostoma orbiculatum, a species not mentioned or discussed by Bakalin in the text. All three mentioned differences from Solenostoma inundatum var. inundatum, esp. larger midleaf cells, convex trigones in the midleaf and strongly thickend external wall of the leaf margin, are typical for Solenostoma orbiculatum. Also mostly brownish plants, suborbicular to reniform, decurrent leaves, fusiform to obpyriform perianths etc. are typical for Solenostoma orbiculatum, not Solenostoma inundatum. 
Solenostoma orbiculatum (Colenso) R.M.Schust., Beih. Nova Hedwigia 119: 380, 2002 (Schuster 2002). Basionym: Gymnomitrion orbiculatum Colenso, Trans. \& Proc. New Zealand Inst. 18: 236, 1886 (Colenso 1886). Type: NEW ZEALAND. Waipawa Co.: Mangatawhainui river, near Norsewood, 10.1884 Colenso (lectotype: WELT!, isotypes BM!, JE!, Herb. Hodgson 13674!, 13691!)

= Solenostoma inundatum var. grandirete Bakalin, Polish Bot. J. 58: 135, 2013 (Bakalin 2013) syn. nov. Type: NEW ZEALAND: Great Barrier Island, s.d. Hutton 3 (holotype NY-1717891!).

\section{Acknowledgements}

The Early Land Plants Today project (ELPT) has been generously supported in part by the Global Biological Information Facility (GBIF) Seed Money Award No.2007-41, activities facilitated in part by funding from the Biodiversity Synthesis Center of the Encyclopedia of Life (BioSynC), partial funding from the National Science Foundation (Award No's 0749762, 1115002), the Warwick Foundation, and the Negaunee Foundation.

\section{References}

Amakawa, T. (1956) Notes on Japanese Hepaticae (2). Journal of Japanese Botany 31: 47-50.

Amakawa, T. (1957) Notes on Japanese Hepaticae (3). Journal of Japanese Botany 32: 34-41.

Amakawa, T. (1959) Notes on Japanese Hepaticae (9). Journal of Japanese Botany 34: 111-116.

Amakawa, T. (1960) Family Jungermanniaceae of Japan II. Journal of the Hattori Botanical Laboratory 22: 1-90.

Amakawa, T. (1966) New or little known Asiatic species of the family Jungermanniaceae. II. Journal of the Hattori Botanical Laboratory 29: 253-266.

Amakawa, T. (1967) New or little known Asiatic species of the family Jungermanniaceae. III. Journal of the Hattori Botanical Laboratory 30: 181-198.

Amakawa, T. (1968) New or little known Asiatic species of the family Jungermanniaceae. IV. Journal of the Hattori Botanical Laboratory 31: 101-112.

Amakawa, T. (1970) New or little known Asiatic species of the family Jungermanniaceae. VI. Jungermannia comata Nees and its allies. Journal of the Hattori Botanical Laboratory 33: 153-160.

Bakalin, V.A. (2005) Monografičeskâ̂ obrabotka roda Lophozia (Dumort.) Dumort. s. str. 240 pp., Nauka, Moscow.

Bakalin, V.A. (2009a "2008”) New liverwort records from Sakhalin Province. 3 [Novye nahodki pečënočnikov v Sahalinskoj oblasti. 3]. Arctoa 17: 226-230.

Bakalin, V. A. (2009b "2008”) On taxonomy of some hepatics from Primorsky Territory (Russian Far East), with the list of taxa of the territory [O taksonomii nekotoryh pečenonikov Primorskogo kraâ (Rossijskij Dal'nij Vostok) so spiskom taksonov, izvestnyh v krae]. Arctoa 17: 101-108.

Bakalin, V.A. (2013) New taxa of Solenostoma and Plectocolea and other taxonomic novelties based on study of collections in the New York Botanical Garden herbarium. Polish Botanical Journal 58: 127-142. http://dx.doi.org/10.2478/pbj-2013-0014

Bakalin, V.A., Cherdantseva, V.Y., Ignatov, M.S., Ignatova, E.A. \& Nyushko, T.I. (2010 “2009”) Bryophyte flora of the South Kuril Islands (East Asia). Arctoa 18: 69-114.

Bakalin, V.A. \& Vilnet, A.A. (2010 “2009”) Two new species of Jungermanniaceae from Asiatic Russia [Dva novyh vida Jungermanniaceae iz aziatskoj časti Rossii]. Arctoa 18: 151-162.

Bakalin, V.A. \& Vilnet, A.A. (2012) New combinations and new species of Solenostoma and Plectocolea (Solenostomataceae) from the Russian Far East. Bryologist 115: 566-584. http://dx.doi.org/10.1639/0007-2745-115.4.566

Buch, H. (1936) Suomen Maksasammalet. Otava, Helsinki, 117 pp.

Colenso, W. (1886) A description of some newly-discovered cryptogamic plants. Transactions and Proceedings of the New Zealand Institute 18: 219-255.

Damsholt, K. (2002) Illustrated flora of Nordic liverworts and Hornworts. Nordic Bryological Society, Lund, 837 pp.

Damsholt, K. (2011) Liverworts collected during the Norwegian east Greenland expeditions 1929-1933. Lindbergia 33: 92-113.

De Notaris, G. (1859) Appunti per un nuovo censimento delle epatiche italiane. Memorie della reale accademia delle scienze di Torino, ser. 2 18: 457-498. 
Dickson, J. (1793) Fasciculus tertius Plantarum Cryptogamicarum Britanniae. G. Nichol, London, 24 pp.

Engel, J.J. (2007) Studies of New Zealand Hepaticae. 20-38. A miscellanea of new taxa and combinations. Novon 17: 310-314. http://dx.doi.org/10.3417/1055-3177(2007)17[310:SONZHA]2.0.CO;2

Feldberg, K., Hentschel, J., Bombosch, A., Long, D.G., Váňa, J. \& Heinrichs, J. (2009) Transfer of Gottschelia grollei, G. patoniae and Scaphophyllum speciosum to Solenostoma based on chloroplast DNA rbcL sequences. Plant Systematics and Evolution 280: 243-250. http://dx.doi.org/10.1007/s00606-009-0187-3

Frye, T.C. \& Clark, L. (1943) Hepaticae of North America. Part II. University of Washington Press, Seattle, pp. 163334.

Gambaryan, S.K. (1992) [Hornworts and liverworts of South Primorie]. Akademia Nauk, Vladivostok, 175 pp.

Gottsche, C.M. (1890) Die Lebermoose Süd-Georgiens. In: Neumayer, G.B. (Ed), Die Internationale Polarforschung 1882-83. Die Deutsche Expeditionen und ihre Ergebnisse. II Beschreibende Naturwissenschaften. A. Asher \& Co.: Berlin, pp. 449-454.

Gottsche, C.M., Lindenberg, J.B.G. \& Nees von Esenbeck, S.G. (1847) Synopsis Hepaticarum, fasc. 5. Meissner, Hamburg, pp. 625-834.

Gray, S.F. (1821) Natural arrangement of British Plants, according to their relation to each other. London, $824 \mathrm{pp}$.

Griffith, W. (1849) Notulae ad Plantae Asiaticas. Part II. On the higher cryptogamous plants. Bishop's college Press, Calcutta, pp. 257-628.

Hattori, S. (1944) Contributio ad Floram Hepaticarum Austro-Kiushiuensem. Bulletin of the Tokyo Science Museum 11: $1-203$.

Hattori, S. (1950 “1948”) Contributio ad Floram Hepaticarum Yakusimensem. III. Journal of the Hattori Botanical Laboratory 3: 1-35.

Heeg, M. (1893) Die Lebermoose Niederösterreichs. Verhandlungen der Kaiserlich-Königlichen ZoologischBotanischen Gesellschaft in Wien 43: 63-148.

Hentschel, J., Paton, J.A., Schneider, H. \& Heinrichs, J. (2007) Acceptance of Liochlaena Nees and Solenostoma Mitt., the systematic position of Eremonotus Pearson and notes on Jungermannia L. s. 1. (Jungermanniidae) based on chloroplast DNA sequence data. Plant Systematics and Evolution 268: 147-157. http://dx.doi.org/10.1007/s00606-007-0549-7

Hooker, W.J. (1813) British Jungermanniae: being a history and description, with figures, of each species of the genus, and microscopical analysis of the parts, vol. 9-15. Longmans, London, pp. 33-60.

Hooker, W.J. (1814) British Jungermanniae: being a history and description, with figures, of each species of the genus, and microscopical analysis of the parts, vol. 16-17. Longmans, London, pp. 61-68.

Hooker, W.J. (1815) British Jungermanniae: being a history and description, with figures, of each species of the genus, and microscopical analysis of the parts, vol. 18-19. Longmans, London, pp. 69-76.

Hooker, J.D. \& Taylor, T. (1844): Hepaticae Novae Zelandiae et Tasmaniae; being characters and brief descriptions of the Hepaticae discovered in the Islands of New Zealand and Van Diemen's Land, during the Voyage of H. M. Discovery ships Erebus and Terror, together with those collected by R. C. Gunn and W. Colenso Esqrs. London Journal of Botany 3: 556-582.

Horikawa, Y. (1934) Monographia Hepaticarum Australi-Japonicarum. Journal of Science of the Hiroshima University: Series B, Division 2 (Botany) 2: 101-325.

Jensen, C.E.O. (1912) Aplozia pusilla, nov. sp. Revue Bryologique 39: 92-94.

Konstantinova, N.A., Potemkin, A.D. \& Šlâkov, R.N. (1992) Checklist of the Hepaticae and Anthocerotae of the former USSR. Arctoa 1: 87-127.

Konstantinova, N.A. \& Vilnet, A.A. (2010 "2009") New taxa and new combinations in Jungermanniales (Hepaticae). Arctoa 18: 65-67.

Lindberg, S.O. (1867) Förteckning öfver mossor, insamlade under de svenska expeditionerna till Spitsbergen 1858 och 1861. Öfversigt af Kongl. Vetenskaps-Akademiens Förhandlingar 23: 535-561.

Lindberg, S.O. (1874) Manipulus muscorum secundus. Notiser ur Sällskapets pro Fauna et Flora Fennica Förhandlingar 13: 351-417.

Massalongo, C.B. (1903) Le epatiche dell'erbario crittogamico italiano: revisione critica. G. Bresciani, Ferrara, 20 pp.

McNeill, J., Barrie, F.R., Buck, W.R., Demoulin, V., Greuter, W., Hawksworth, D.L., Herendeen, P.S., Knapp, S., Marhold, K., Prado, J., Prud'homme van Reine, W.F., Smith, G.F., Wiersema, J.H. \& Turland, N.J. (2012) International Code of Nomenclature for algae, fungi and plants (Melbourne Code) adopted by the Eighteenth International Botanical Congress Melbourne, Australia, July 2011. Regnum Vegetabile 154: 1-240.

McNeill, J., Barrie, F.R., Burdet, H.M., Demoulin, V., Hawksworth, D.L., Marhold, K., Nicolson, D.H., Prado, J., Silva, P.C., Skog, J.E., Wiersema, J.H. \& Turland, N.J. (2006) International Code of Botanical Nomenclature (Vienna Code) adopted by the Seventeenth International Botanical Congress Vienna, Austria, July 2005. Regnum Vegetabile 
146: $1-260$.

Mitten, W. (1861) Hepaticae Indiae Orientalis: An enumeration of the Hepaticae of the East Indies. Journal of the Proceedings of the Linnean Society. Botany 5: 89-128.

Mitten, W. (1865): The "Bryologia" of the survey of the $49^{\text {th }}$ parallel of latitude. Journal of the Linnean Society of London 8: 12-55.

Mitten, W. (1870) Hepaticae. In: Godman, F. (Ed), Natural History of the Azores, or Western Islands. Van Voorst: London, pp. 316-328.

Mitten, W. (1873 “1871”) Jungermanniae and Marchantiae. In: Seemann, B. (Ed), Flora vitiensis. Reeve: London, pp. 325-453.

Mitten, W. (1891) An enumeration of all species of Musci and Hepaticae recorded from Japan. Transactions of the Linnean Society of London. Botany 3: 153-206.

Müller, K. (1947) Morphologische Untersuchungen zur Aufklärung einiger europäischer Lebermoose. Beiträge zur Kryptogamenflora der Schweiz 10(2): 1-55.

Nees von Esenbeck, C.G. (1830) Enumeratio plantarum cryptogamicarum Javae et insularum adiacentium, quas a Blumio et Reinwardtio collectas describi edique curavit Christ. Godofr. Nees ab Esenbeck professor vratislaviensis. Fasciculus prior, hepaticas complectens, ab editore illustratas. Grass, Barth \& Co., Breslau, 86 pp.

Nees von Esenbeck, C.G. (1833) Naturgeschichte der Europäischen Lebermoose mit besonderer Beziehung auf Schlesien und die Oertlichkeiten des Riesengebirgs, vol. 1. August Rücker, Berlin, 348 pp.

Nees von Esenbeck, C.G. \& Montagne, J.F.C. (1836) Jungermanniearum Herbarii Montagneani species. Annales des Sciences Naturelles; Botanique, sér. 2 5: 52-72.

Paton, J.A. (1999) The liverwort flora of the British Isles. 626 pp., Harley Books, Colchester.

Pearson, W.H. (1892) Lejeuneae Madagascariensis. Forhandlinger i Videnskabs-Selskabet i Kristiania 1892(8): 3-9.

Potemkin A.D. \& Sofronova E.V. (2009) Pečënočniki i antocerotovye Rossii 1. Russian Academy of Sciences, Komarov Botanical Institute, Saint Petersburg \& Jakutsk, 367 pp.

Schiffner, V. (1909) Hepaticae (In: Handel-Mazzetti H.M. (Ed.), Ergebnisse einer botanische Reise in das Pontische Randgebirge im Sandschak Trapezunt). Annalen des K. K. Naturhistorischen Hofmuseums 23: 133-141.

Schiffner, V. (1910) Kritische Bemerkungen über die europäischen Lebermoose mit Bezug auf die Exemplare des Exsiccatenwerkes: Hepaticae europaeae exsiccatae VIII (363-376). Lotos. Zeitschrift für Naturwissenschaften 58: 314-333.

Schuster, R.M. (1953) Boreal Hepaticae. A manual of the liverworts of Minnesota and adjacent regions. American Midland Naturalist 49(2): 257-684. http://dx.doi.org/10.2307/2422089

Schuster, R.M. (1969) The Hepaticae and Anthocerotae of North America east of the Hundredth Meridian. Vol. 2. Columbia University Press, New York \& London, 1060 pp.

Schuster, R.M. (2002) Austral Hepaticae. Part II. Beihefte zur Nova Hedwigia 119: 1-606.

Schuster, R.M. \& Damsholt, K. (1974) The Hepaticae of West Greenland from ca. $66^{\circ} \mathrm{N}$ to $72^{\circ} \mathrm{N}$. Meddelelser om Grønland 199(1): 1-373, 80 map.

Schljakov, R.N. (1980) Novye interesnye nahodki pečenočnikov iz severnyh rajonov SSSR [De hepaticis in regionibus borealibus URSS inventis novis et curiosis notula]. Novosti Sistematiki Nizših Rastenij 17: 235-241.

Smith, J.E. \& Sowerby, J. (1811) English Botany, vol. 32. J. Davis, London, pp. 2233-2304.

Söderström, L., Hagborg, A. \& von Konrat, M. (2012) Notes on Early Land Plants Today. Phytotaxa 65: 41-42.

Stephani, F. (1897) Hepaticae Japonicarum. Bulletin de l'Herbier Boissier 5: 76-108.

Stephani, F. (1901) Species Hepaticarum 2. Bulletin de l'Herbier Boissier, série 2 1: 477-521.

Stephani, F. (1902) Species Hepaticarum 2. Bulletin de l'Herbier Boissier, série 2 2: 35-48.

Stephani, F. (1917a) Species Hepaticarum 6. George \& Cie, Genève \& Bale, pp. 1-128.

Stephani, F. (1917b) Species Hepaticarum 5. George \& Cie, Genève \& Bale, pp. 1009-1044.

Underwood, L.M. (1888) Some undescribed hepaticae from California. Botanical Gazette 13(5): 112-114. http://dx.doi.org/10.1086/326267

Váňa (1970) Jungermannia caucasica sp. n. (Hepaticae). Preslia 42: 96.

Ván̆a, J. (1972) Miscellaneous notes on the Asiatic Jungermannioideae. Journal of the Hattori Botanical Laboratory 35 : 312-318.

Váňa, J. (1973 “1972”) Miscellaneous notes on the Asiatic Jungermannioideae II. Journal of the Hattori Botanical Laboratory 36: 57-74.

Váňa, J. (1974a) Studien über die Jungermannioideae (Hepaticae). 4. Jungermannia subg. Plectocolea und subg. Solenostoma: Allgemeines, süd- und mittelamerikanische Arten. Folia Geobotanica et Phytotaxonomica 9: 179208.

Váňa, J. (1974b) Studien über die Jungermannioideae (Hepaticae). 5. Jungermannia subg. Plectocolea und subg. Solenostoma: Afrikanische Arten. Folia Geobotanica et Phytotaxonomica 9: 277-312. 
Váňa, J. (1974c) Studien über die Jungermannioideae (Hepaticae). 6. Jungermannia subg. Solenostoma: Europäische und nordamerikanische Arten. Folia Geobotanica Phytotaxonomica 9: 369-423.

Váňa, J. (1975) Studien über die Jungermannioideae (Hepaticae). 7. Jungermannia subg. Plectocolea: Europäische und nordamerikanische Arten. Folia Geobotanica Phytotaxonomica 10: 67-99.

Ván̆a, J. (1976) Studien über die Jungermannioideae (Hepaticae). 10. Nardia. Folia Geobotanica et Phytotaxonomica 11: $367-425$.

Váňa, J. \& Engel, J.J. (2013) The liverworts and hornworts of the Tristan da Cunha group of islands in the south Atlantic Ocean. Memoirs of the New York Botanical Garden 105: 1-138.

Váňa, J., Hentschel, J. \& Heinrichs, J. (2010) New combinations in Jungermanniales: transfer of 32 taxa to Solenostoma Mitt. Cryptogamie, Bryologie 31: 135-139.

Ván̆a, J. \& Engel, J. J. (2013) The liverworts and Hornworts of the Tristan da Cunha group of Islands in the South Atlantic Ocean. Memoirs of The New York Bot. Garden 105: i-x, 1-138, figs. 1-11.

Váňa, J., Hentschel, J. \& Heinrichs, J. (2010) New combinations in Jungermanniales: transfer of 32 taxa to Solenostoma Mitt. Cryptogamie, Bryologie 31(2): 135-139.

Ván̆a, J. \& Ignatov, M.S. (1995): Bryophytes of Altai Mountains. V. Preliminary list of the Altaian hepatics. Arctoa 5: 113.

Váňa, J. \& Inoue, H. (1983) Studies in Taiwan Hepaticae. V. Jungermanniaceae. Bulletin of the National Science Museum, Tokyo. Series B, Botany 9: 125-142.

Váňa, J. \& Long, D.G. (2009) Jungermanniaceae of the Sino-Himalayan region. Nova Hedwigia 89: 485-517. http://dx.doi.org/10.1127/0029-5035/2009/0089-0485

Ván̆a, J., Söderström, L., Hagborg, A. \& von Konrat, M. (2012) Notes on Early Land Plants Today. 2. Two new combinations in Solenostoma. Phytotaxa 65: 44.

Vilnet, A.A., Konstantinova, N.A. \& Troitsky, V.A. (2008) Phylogeny and systematics of the genus Lophozia s. str. (Dumort.) Dumort. (Hepaticae) and related taxa from nuclear ITS1-2 and chloroplast trnL-F sequences. Molecular Phylogenetics and Evolution 47: 403-418. http://dx.doi.org/10.1016/j.ympev.2007.12.013

Vilnet, A.A., Milyutina, I.A., Konstantinova, N.A., Ignatov, M.S. \& Troitsky, V.A. (2007) Phylogeny of the Genus Lophozia (Dumort.) Dumort. s. str. inferred from nuclear and chloroplast sequences ITS1-2 and TRNL-F. Russian Journal of Genetics 43: 1556-1564.

http://dx.doi.org/10.1134/S1022795407110142

Withering, W. (1796) An arrangement of British Plants, ed. 3. London, pp. 513-920. 